\title{
A Escola de Serviço Público
}

\section{OSCAR Victorino Moreira}

S conhecimentos sôbre administração pública não constituíam matérias consideradas para efeito de uma disciplinação, até que - Departamento Administrativo do Serviço Público encarou o assunto, criando os "Cursos de Administração". Tudo que antes era feito decorria de tentativas isoladas, partidas de alguns que viam a necessidade, mas não se subordinava a uma programação regular, a uma fixação de objetivos precisos; era o empirismo presidindo as ações.

Criados os Cursos de Administração, começou a fase experimental, sendo colhidos resultados compensadores, notando-se tentativas de várias naturezas, ditadas pelas necessidades do mo mento. Por vêzes, organizavam-se cursos especificos para atender a um determinado objetivo, atingido o qual, encerravam-se. Regularmente, poucos cursos funcionavam, até que a prática demonstrou ser imperiosa a criação de cursos regulares. Assim é que surgiram os cursos de formação, de currículo, seriados, já produzindo bons resultados .

Essa foi, evidentemente, a fase inicial da escola, mas não poderemos permanecer ai, pois a administração pública se vem ressentindo da falta de pessoal capacitado para o desempenho das mais variadas atividades.

Num mundo em que a juventude desempenha, cada vez mais, importante papel no desenvolvimento de seus paises, a par de sua contribuição para o aprimoramento das atividades, os problemas educacionais tornaram-se cruciais, mister se fazendo o oferecimento de meios para que ela possa capacitar-se. Não deverá ser-lhe ministrada uma educação puramente formal ou acadêmica, em moldes de cultura desinteressada, mas eficiente, prática, capaz de atender às necessidades da hora presente, em incessante processo de transformação, sobretudo nos domínios da ciência e, principalmente, da tecnologia.

A administração pública que abarca todos os ramos de atividade, dado seu polimorfismo, exige a formação de grandes 
quadros técnicos, como a constante preparação de especialistas altamente qualificados, o que podemos concluir ser uma aspiração nacional, além de sua evidente necessidade. A educação não pode restringir-se aos seus aspectos tradicionais e formais, o mundo atual exige muito mais, pois a competição em que nos encontramos é sua determinante. De hábito, ouvem-se lamentos quanto ao despreparo dos elementos que desempenham atividades públicas, mas as providências indispensáveis para eliminar-se as deficiências não são tomadas, apenas a crítica, o lamento.

E' forçoso reconhecer os sadios exemplos dos cursos de administração, sejam os pioneiros do D.A.S.P., sejam os da Fundação Getúlio Vargas, assim como hoje vêm despontando outros através do Brasil, o que constitui inegável benefício ao desenvolvimento, não só da administração pública, mas de todo o País.

A Escola de Serviço Público já se acha credenciada para passar a uma fase mais avançada, isto é, deverá manter os cursos do nivel atual, principalmente para formação, a par das atividades de treinamento ou de aperfeiçoamento funcional, mas é reconhecida, de um modo geral, a necessidade de cursos de nivel superior, de cursos onde sejam disciplinadamente estudados problemas nacionais, de imediato ou mediato interêsse da administração pública.

O administrador não pode ser pr oduto espontâneo, deve formar-se, capacitar-se regularmente, pois o tempo do empirismo está superado e os países que se mantiverem nêle permanecerão no subdesenvolvimento. A técnica é uma associação de teoria e prática, e a teoria é obtenível nos bancos escolares. Técnica de oitiva, ou obtida na prática, são absurdos, assim como os chamados técnicos sem provarem por meios hábeis que o são. Há casos em que os rótulos de técnico se aplicam como apelidos aos funcionários!

A Escola de Serviço Público deve prestar êsse inestimável serviço ao País, deve preparar-se para a formação e o aperfeiçoamento do pessoal em nivel superior, pois a falta dêsses elementos constitui uma realidade, por todos verificada.

Não deverá deixar de prestar o valioso auxílio que tem até hoje prestado à administração pública, mas é de seu dever a habilitação para prestar mais serviços. Se, para isso, fôr necessária alguma lei nova, que se promova, pois a lei nada mais é que disciplina, que autorização, não será a sua necessidade o fator impeditivo. Promova-se a lei, demonstre-se a sua necessidade, para alcançarmos no menor tempo possivel as condições exigidas pelas imposições da hora presente, e mais, pelas futuras e próximas condições do Mundo em que vivemos. O Brasil deve preparar-se para embates muito maiores do que os enfrentados 
até hoje e a instrução representa um dos maiores fatôres de fortalecimento de uma nacionalidade, assim como podemos afirmar, sem receio de êrro, que a instrução é investimento altamente lucrativo para qualquer povo.

Apenas para evidenciarmos um aspecto da questão da for mação em nivel superior, bastaria lembrarmos que a escolha de dirigentes, e principalmente os de direção superior, é feita com base no conhecimento pessoal, sem que se exija a comprovação de capacidade para aquêle mister. Haverá lógica em exigirmos comprovação de conhecimentos daquele que inicia sua carreira, nas mais modestas funções, mas nada exigir -se dos que devam exercer os mais elevados cargos, os das maiores responsabilidades, os que necsesitam de pessoal altamente capacitado, possuidor de mais aprimorada técnica? O irracional impera, mas é preciso pormos um fim e, para isso, nenhuma outra solução será melhor que a formação de pessoal de nivel superior em administração pública, assim como de seu aperfeiçoamento. O momento é crucial e decisivo, exigindo de parte do Poder Público uma atitude corajosa e eficiente, sendo-nos permitido sugerir o aparelhamento da Escola de Serviço Público para tal fim, mas não se limitando ao funcionamento na cidade do Rio de Janeiro e, sim, nas capitais de todos os Estados desta Federação. 